\title{
COMPUTER-AIDED EXERCISES IN TRAINING COMMANDERS AND HQ STAFF: NOTE ON BULGARIAN EXPERIENCE
}

\section{Alexi NAIDENOV}

$\mathrm{T}$ The increasing complexity of the problems, facing the society and the military, the limited resources the armed forces operate with, as well as the overwhelming flow of information all call for increasing efficiency and effectiveness training of the staff, involved in decision making. That, among other things, will help them develop agile and inquisitive personalities.

The demanding nature of the command in a complex environment requires constant training that creates extreme situations developing even faster than real-life ones. The point is to work out a mechanism for fast and adequate reaction to problem situations by putting a man in conditional and probable situations created by imitation and modeling. ${ }^{1}$ The immediate outcome of this is the adequate reaction to the presented extreme situation. This concerns mainly the officers and HQ staff of the Bulgarian Armed forces, because the shortening education and training period concurs with the widening range of requirements put forth. ${ }^{2}$

Both the transition to a new organizational and staff structure and the increasing importance of the officers' professionalism call for quantitative and qualitative improvement of the training of HQ staff, as well as the HQ command exercises. Furthermore, this has to be accomplished in times of continuous shortage of funds. Improving the HQ's organization, lowering spending as much as possible and eliminating the risk of human loss or environmental damage is a vital issue for any military organization. These requirements limit even more both the chances of proper utilization and putting into practice of the skills gained to date and the testing of the training process and combat readiness. The main way for dealing with these circumstances is the search for, and application of, new training programs for the commanders and headquarters' staff (HQS) that will create working conditions adequate for the command of the military forces in near combat conditions. 
The experience of the armed forces of NATO member countries and the limited Bulgarian experience show that main way of improving the commanders and HQS preparation is the implementation of computer-aided exercises.

The computer-aided commanders and staff exercises are a modern and effective training method for the operational and tactical formations. ${ }^{3}$ They aim at developing certain skills in the commanders and HQS that will later help them optimize the current HQ procedures and functions. In the armed forces of NATO member countries the computer-aided exercises comprise approximately sixty percent of all exercises and this figure rises each year.

Depending on the training objectives, the problems solved, the trained staff, the precision of presenting the forces, weapon systems and location, and the impact of other factors, the computer-aided exercises can be categorized in three thematic groups ${ }^{4}$ :

\section{Group exercises;}

2. Comprehensive exercises;

3. Detailed exercises.

The group exercises have a limited number of participants and hierarchical levels. Using a comprehensive simulation model, they deal with a small number of issues that represent just a part of the combat. The modeling is quick and allows us to concentrate on the aims and objectives of the exercise.

The comprehensive exercises have broader objectives and all staff members with functional duties, pertinent to achieving the objectives, take part in the exercise. In these exercises the separate combat episodes are not emulated in detail but are analyzed instead from a broader perspective. The operation of training HQS is in real time

The detailed exercises have specific objectives and involve a great number of organizational units. In the process of their modeling lower organizational levels and larger number of factors, that impact the combat, are being acknowledged. They use a system of models of types of military forces, Special Forces and weapon systems characteristics. The exercise is conducted in real time.

With the help of this table the commander (supervisor) can choose what type of computer-aided exercise to carry out, with the headquarters under his command, while taking into account the preparedness level, number of participants, objectives and available materiel. 
Table 1 summarizes the characteristics of the different groups of computer-aided exercises (CAX):

\begin{tabular}{|l|l|l|l|l|l|l|l|l|l|}
\hline $\begin{array}{l}\text { Type of } \\
\text { CAE }\end{array}$ & $\begin{array}{l}\text { Number } \\
\text { of parti- } \\
\text { cipants }\end{array}$ & $\begin{array}{l}\text { Level of } \\
\text { difficulty }\end{array}$ & Price & Time & $\begin{array}{l}\text { Needed } \\
\text { preparation }\end{array}$ & $\begin{array}{l}\text { Difficulty of } \\
\text { the } \\
\text { objectives }\end{array}$ & $\begin{array}{l}\text { Number } \\
\text { of tasks }\end{array}$ & $\begin{array}{l}\text { Adequacy of } \\
\text { the model }\end{array}$ & Duration \\
\hline Group & small & low & low & $\begin{array}{l}\text { Accelera- } \\
\text { ted }\end{array}$ & $\begin{array}{l}\text { Short and } \\
\text { simple }\end{array}$ & $\begin{array}{l}\text { Limited } \\
\text { objectives }\end{array}$ & Small & $\begin{array}{l}\text { Relatively } \\
\text { comprehend } \\
\text { sive }\end{array}$ & short \\
\hline $\begin{array}{l}\text { Compre- } \\
\text { hensive }\end{array}$ & average & average & average & $\begin{array}{l}\text { Real/ } \\
\text { accelera- } \\
\text { ted }\end{array}$ & moderate & $\begin{array}{l}\text { Broad objec- } \\
\text { tives }\end{array}$ & Average & $\begin{array}{l}\text { Relatively } \\
\text { comprehend } \\
\text { sive }\end{array}$ & average \\
\hline Detailed & large & high & high & real & $\begin{array}{l}\text { Long and } \\
\text { complicated }\end{array}$ & $\begin{array}{l}\text { Diverse and } \\
\text { complicated }\end{array}$ & Large & Detailed & long \\
\hline
\end{tabular}

Functionally, the technology used in computer-aided exercises should meet the following requirements:

- To come as close as possible to the HQ's real life operational environment;

- Commanders and HQS should not be required additional skills in order to perform their duties, i.e. they should use the standard HQ's operational and collaborative procedures;

- Each command staff trainee should comprehensively perform his or her functional duties while organizing the combat operation;

- It should allow the use of graphical information systems and other modules for target analysis, in the area, while facilitating the objective, situation assessment and following HQ actions, i.e., the system should be open and expandable.

- To display real time graphical environment as close to reality as possible;

- Real time display and processing of information should be according to plans;

- The results of the trained commands and orders should be displayed in real time;

- A capability for easy interaction should be provided so that the planned HQ objectives are achieved;

- A capability for statistical output and data storage of different decisions should be provided in order to compare, analyze and study the results of a specific decision made.

The current simulation system used for computer-aided exercises in the Bulgarian armed forces is tested and adopted in 1996. It is designed to perform HQ command computer-aided exercises at the level of all arms brigade. The system provides good 
educational capabilities. However, the systems' mathematical model has the following drawbacks:

- Lack of an integrated database;

- Lack of common mathematical logic;

- Lack of common algorithmic structure.

As a result we can only achieve part of the commands' general objectives.

This is also a reason for us to make a determined effort to develop simulation systems in a relatively short period of time (until 2003) so that the following objectives are achieved:

- Improving the quality of the training of HQS and forces in accordance with the Concept of National Security, the Military Doctrine of the Republic of Bulgaria and the Plan for Organizational Development of the Bulgarian Army until 2004;

- Providing for the operational compatibility with the armed forces of NATO member countries;

- Bringing the training in compliance with the current legislature and criteria founded in the qualification records and requirements for training HQS;

- Reaching optimal utilization of HQS and maximal command efficiency by means of multilateral modeling of major combat processes;

- Unifying (synchronizing) the separate elements of the military education such as: syllabus, methodology, study facilities, qualification, etc., in order to achieve the major objectives of training commanders, HQS, armies and forces;

- Developing a unified and effective model for training commanders, HQS and troops while keeping in mind the qualitative changes in the military science and development of information and management technologies;

- Taking part in certain joint exercises with NATO and "Partnership for Peace" (PfP) member countries and the necessary for that preparation and regular participation in national training exercises similar to those carried out with the neighboring PfP member countries.

The realization of the latter corresponds to decisions of the Washington Summit of NATO in April 1999. The Nrth Atlantic Council issued a resolution for further development and utilization of new defense information technologies and secure integrated computer communication network among PfP member countries. It is envisioned that the network will be based on three major subsystems: 
- Consortium among the military education facilities and so unifying their curricula;

- A unified network of functional crisis management centers;

- A network of the general headquarters used for performing HQ command computer simulated exercises.

Last year, in compliance with that resolution, together with PfP member countries, a shared HQ command exercise was carried out called "Peace Shield 2000". The exercise was particularly important for the Bulgarian armed forces because one of the centers was situated in the country. The exercise was carried out between the $8^{\text {th }}$ and $22^{\text {nd }}$ of July 2000 . There were 21 participating countries divided in two multinational brigade headquarters, acting as multinational battalion headquarters, and several formations all operating on the battlefield.

The aim of the exercise was both to organize the multinational headquarters and, in reality, to resolve issues on tactics improvement and methods for conducting peacekeeping operations by means of computer modeling, implementation of new information technologies and communication systems.

The exercise was conducted on the "Javoriv" training facility near Lvov, Ukraine, using four remote command posts, one of which was the Command and Coordination Center. The other three command posts were Combat Preparation Centers in Bulgaria, Estonia and Ramstein Air Base - Germany. There were two battalion headquarters - Bulgarian and Moldavian.

In the course of the exercise all trainees faced the following major objectives:

- Organizing the multinational brigade headquarters taking part in the peacekeeping operation while developing general procedures on conduct (rules of engagement) and planning;

- Improving the command and control methods for peacekeeping operations;

- Improving the readiness to organize and provide for operations while gaining experience in similar operations and exercises;

- Improving the collaboration among participants in peacekeeping operations;

- Allowing staff members to exchange information on peacekeeping operations;

- Encouraging mutual trust and respect among staff members of the participating countries;

- Implementing and improving the technology that supports the exercises on the "Partnership for Peace" Program. 
Organizers of the "Peace Shield 2000" exercise were the European command of U.S. Forces, the National Guard of Illinois and the Ukrainian MOD.

The exercise was carried out in five major stages as follows:

I. Deployment of the Combined Peacekeeping Forces (CPKFOR-00) to the ordered location.

II. Preparing CPKFOR-00 for organizing the multinational command structure and establishing standard operational procedures on all HQ levels. Training units to perform the major objective for a given location.

III. Replacement of CPKFOR-99 command with that of CPKFOR-00. Establishing the temporary joint-activities headquarters until taking tactical control over the units and conducting orientation meetings of all commanders on the operation and their responsibilities.

IV. Conducting the peacekeeping operation.

V. Devolving CPKFOR-00 powers to the Federal Government after holding elections, reaching long-lasting peace and conducting redeployment to national bases.

A satellite connection was established, between the Center for Combat Training of the U.S. Army in Ramstein Air Base and the "Yavoriv" training facility near Lvov, Ukraine, for the command of both the multinational brigade and battalion headquarters. Hosting countries also provided ISDN channels among all remote command posts in Bulgaria and Estonia allowing diverse means of communications. High-speed broadband networks integrating different means of communications, such as telephone, fax, video data transfer and new multimedia services, combining text, sound and picture in various applications, remodel completely the way of managing, processing, transferring and exchanging information and so gave an advantage in terms of time and distance.

During the exercise the Bulgarian and Moldavian battalion headquarters used the following ISDN services:

- Basic Rate Access (BRA) also known as $2 \mathrm{~B}+\mathrm{D}$ provides a standard subscriber line allowing simultaneous communication on both channels with transfer speeds of up to $64 \mathrm{Kbit} / \mathrm{s}$ for the '2B' channel and $16 \mathrm{Kbit} / \mathrm{s}$ for the 'D' channel;

- ISDN telephone - modern multifunctional telephones equipped with message and control display;

- Telecommunications services - Information exchange between two or more subscribers (trilateral and conference connection); 
- Multiple Subscription Number (MSN) - ISDN, characterized by flexible number determination.

While organizing the exercise the following advantages of the ISDN lines became apparent:

- High quality and dependability of the connections. The transfer of digital data was hardly affected by noise and errors on the line. Wherever errors occurred, in the network, the transfer was relocated to alternative routes and, thus, did not affect the exercise;

- Transfer speed. Both communication channels, each carrying $64 \mathrm{Kbt} / \mathrm{s}$ of data, provided speech, text, graphic, and video data transfer using a PC;

- One line gives access to all services, similar tariffs and uses a single longdistance connection interface;

- Fast dialing. The digital equipment allowed much faster dialing the brigade headquarters - a matter of 3 to 4 seconds;

- Single standard. EURO standard valid in our national network assured the compatibility of the ISDN networks of all countries, end devices and equipment.

The exercise uses the JCATS 2.0 (Joint Conflict and Tactical Simulation) system that is multilateral, interactive, high-resolution and comprehensive. The ways of using this new model can be summarized as follows:

- Modeling operations, usually military operations other than war, that combines economic, social, military, and political activities by using comprehensive, strictly specific and characteristic of the operations' local area database;

- Simulation of different types of combat;

- Modeling combat and non-combat activities in cities by using detailed records of existing buildings, location characteristics, roads and communication facilities.

The JCATS 2.0 model covers the levels from company to brigade inclusively and allows the battalion headquarters to execute four to seven tasks daily, including:

- Refugee convoy;

- Humanitarian aid convoy;

- Controlling mass demonstrations;

- Giving first aid to wounded and injured personnel;

- Designation of mines and mine fields; mine clearing; 
- Detaining weaponry and drugs traffickers;

- Detaining terrorists;

- Water, fuel, food and ammunition supply;

- Evacuating wounded and injured personnel;

- Supplying mass, religious and holiday activities with food.

All those tasks were developed with the simulation system. They all required the input of specific objectives, unit collaboration procedures, and subalterns' duties.

Besides using the models' role-playing feature, battalion HQs solved the following problems:

- Conducting negotiations with mayors and other official representatives of the local government;

- Giving first aid to young mothers and sick children;

- Organizing the cooperation with the local police, paramilitary organizations and formations.

For the first time the exercise featured WEU and NATO candidate member countries. The participation of the Republic of Bulgaria, as a hosting country of one of the centers of the exercise, was highly appreciated by both the organizers of the exercise and the European command of US Air Forces. The exercise allowed the participating Bulgarian officers to gain skills and experience while working in multinational headquarters and to learn the operational procedures for conducting peacekeeping operations.

The conduct of the computer-aided exercise and field exercise proved to be highly effective in training headquarters and units for achieving mission objectives.

The computer-aided exercise pointed out a number of advantages of the simulation system for training commanders and HQS. They can be summarized as follows:

- Bringing the working environment as close as possible to a real combat situation. The trainees took full advantage of this fact and used all systems' capabilities available;

- In that kind of exercises organizing the HQ and its capability to quickly assess the current situation is of greatest importance. The systems capability of multiple repetition of certain situations proved clearly that HQ Command efficiency is of paramount importance;

- The Command of the exercise skillfully guided the actions of the imitation groups so that the trained HQ could act in a dynamic environment demanding untraditional solutions; 
- The decision making process, unit command and bilateralism of the exercise were brought as close to reality as possible;

- The simulation system allowed the Command of the exercise to experiment with some of the HQ's tasks that were considered problematic. The use of this tool also generated a more efficient training strategy.

- The Command Center was able to provide analysis and documentation for the complete course of the exercise and also records for the trained situations and orders. All that was used for the daily and final breakdown of the exercise. In addition, the archiving of the results of the exercise gave the commanders detailed records for later usage.

- The objectivity of the modeling system stimulated the resourcefulness of each commander and the models' output, for each decision in the peacekeeping operation, made them more confident. In addition the analysis of different situations and variants encouraged their creative thinking and learning.

In conclusion we can say that the analysis of the conducted exercises and our experience in the Partnership for Peace Program undoubtedly proved that computeraided exercises are a new and promising way of training officers and HQS. At the same time, they must not be accepted unconditionally and as utmost value - real life human experience, gained in field activities, should not be brushed aside. In the future we must achieve a proper balance between field and computer aided exercises so to provide for the most effective training and commanders and staff of headquarters. 


\section{Notes:}

1 G. Brewer and M. Sbubik, The War Game: A Critique of Military Problem Solving (Cambridge, MA: Harvard University Pres, 1979).

2 Described in detail in Nikolay Vraikov and Alexi Naidenov, "The Computer- Aided Exercise - An Alternative of the Conventional Exercises in the Armed Forces," Information \& Security: An International Journal 3 (2000): 119-131.

3 Valentin Penev, "Simulation Modeling in Military Affairs: Status and Perspectives," Information \& Security: An International Journal 1, 1 (Summer 1998): 91-102.

4 Alexi Naidenov adn Nikolay Vraikov, Computer assisted Exercises (Sofia; Military Publishing House, 2000).

ALEXI NAIDENOV is Colonel in the Bulgarian Army, chief of "Exercises, Training and War games" Department at the Operations Directorate of the General Staff. In 1977 he graduated from "V. Levski" Army Academy in Veliko Tyrnovo, Bulgaria. Then he served in a number of Land Forces units. In 1986 he graduated from "Frundze" War College in Russia. After that he consecutively took positions at various staffs - Corps HQ, Land Forces Headquarters and General Staff of the Bulgarian Armed Forces. Since 1993 he is involved in designing and implementing the policy of using simulation systems in staff and troops training. E-mail: aleksi_NAC@yahoo.com. 